\title{
EFFECT OF DRY-WET CIRCULATION ON THE MECHANICAL PROPERTIES AND PORE STRUCTURE OF AUTOCLAVED AERATED CONCRETE
}

\author{
VPLIV SUHO-MOKRE CIRKULACIJE NA MEHANSKE \\ LASTNOSTI IN STRUKTURO POR V AVTOKLAVU \\ PREZRAČENEGA BETONA
}

\author{
Xiao He, Jian Yin*, Jiewen Yang, Qiao Liang, Songyun Wu \\ School of Civil Engineering, Central South University of Forestry and Technology, no. 498 Shaoshan South Road, Tianxin District, Changsha \\ 410004, Hunan, China \\ Prejem rokopisa - received: 2018-08-30; sprejem za objavo - accepted for publication: 2018-10-18
}

doi:10.17222/mit.2018.190

Dry-wet circulation is the main service environment for autoclaved aerated concrete. In this study, we looked at selected autoclaved aerated concrete with dry-wet circulation times of $(0,30,60,150,270$ and 340) min. The tested mechanical properties include the compressive strength and the splitting tensile strength. Scanning electron microscopy (SEM) and Image-Pro-Plus (IPP) software were chosen to quantitatively characterize the microstructure. The results showed that as the dry-wet circulation times increased, the compressive strength decreased after first increasing, and the splitting tensile strength reduced. In addition to the pore structure, microcracks and internal acicular ettringite were produced. The pore size distribution was concentrated from $1.0 \mathrm{~mm}$ to $1.5 \mathrm{~mm}$, when dry-wet cycle times were $60 \mathrm{~min}$ or more.

Keywords: autoclaved aerated concrete, dry-wet circulation, mechanical properties, Image-Pro-Plus, pore structure

Suho-mokra cirkulacija je glavni naravni postopek za prezračevanje betona v avtoklavu. Avtorji opisujejo prezračevanje betona v avtoklavu s suho-mokro 0, 30, 60, 150, 270 in 340-minutno cirkulacijo. Vzorcem betona so nato določili mehanske lastnosti in sicer tlačno ter cepilno trdnost. Kvantitativno so okarakterizirali mikrostrukturo z vrstičnim elektronskim mikroskopom (SEM) in programsko opremo za obdelavo slike Image-Pro-Plus (IPP). Rezultati kažejo, da z naraščajočim časom suho-mokre cirkulacije tlačna trdnost po prvem dvigu v primerjavi $\mathrm{z}$ necirkuliranim betonom pade, cepila trdnost pa se zmanjšuje. $\mathrm{V}$ porozni strukturi betona so nastale mikrorazpoke in interni igličasti etringit (hidroksidni Ca-Al sulfatni mineral). Porazdelitev velikosti por je bila koncentrirana med 1,0 in $1,5 \mathrm{~mm}$ po 60 -minutnem ali še daljšem suho-mokrem ciklu.

Ključne besede: v avtoklavu prezračen beton, suho-mokra cirkulacija, mehanske lastnosti, obdelava slike s programsko opremo Image-Pro-Plus, struktura por

\section{INTRODUCTION}

Autoclaved aerated concrete has good performance with respect to heat preservation and heat insulation, and also saves clay resources. The excellent properties of autoclaved aerated concrete depend on its unique pore structure. ${ }^{1-4}$ But in the actual service process, dry-wet circulation causes deformation. Studies have shown that one of the main factors was the dry-wet circulation. ${ }^{5-7}$ In addition, as the dry-wet circulation times increased, the performance of the heat preservation and heat insulation declined.

Autoclaved aerated concrete, as a wall material, is often in the environment of rainfall infiltration and drying evaporation. Studies showed that dry-wet circulation speeded up the invasion rate of harmful media, such as sulfate and chloride, which lead to destruction, and also changed the moisture content for deformation. Autoclaved aerated concrete with the characteristics of dry shrinkage and wet expansion, for inflation happen

*Corresponding author e-mail:

csuyj700930@163.com when the internal moisture content increased, on the other hand, contraction was produced. Studies also showed that the humidity inside the autoclaved aerated concrete emerged to a graded distribution, and larger internal stress occurred and when the stress exceeds a certain limit, cracking of the autoclaved aerated concrete happened, which results in its unique pore structure being damaged, the mechanical properties declining, and life of service being reduced. ${ }^{8-10}$

This paper studies the relationship between the mechanical properties and the pore structure of the autoclaved aerated concrete under dry-wet circulation. Scanning electron microscopy (SEM) was used to characterize the micro-pore structure. By employing Image-Pro-Plus software to a binary image of the pore structure, we obtained a quantitative characterization of the pore structure, in order to calculate the pore diameter distribution. A fractal dimension was used to characterize the pore size distribution, and the fractal dimension had a quadratic correlation with the mechanical properties though the regression equation. 


\section{EXPERIMENTAL PART}

\subsection{Materials}

Autoclaved aerated concrete was obtained from Changle building materials co. LTD in Changsha, China. Table 1 shows the properties of the autoclaved aerated concrete.

Table 1: Main properties of autoclaved aerated concrete

\begin{tabular}{|c|c|c|c|}
\hline Model & $\begin{array}{c}\text { Bulk } \\
\text { density }\end{array}$ & $\begin{array}{c}\text { Intensity of } \\
\text { average }\end{array}$ & Size \\
\hline A3.5 B06 & $<625$ & $>3.5 \mathrm{MPa}$ & $(600 \times 200 \times 100) \mathrm{mm}$ \\
\hline
\end{tabular}

\subsection{Dry-wet circulation test methodologies}

The methods of the specimens' processing and performance testing were referred to GB/T 11969-2008 "test methods of performance for autoclaved aerated concrete". The dry-wet circulation of a specimen prepared with a sawing machine, chose a group based on the parts from the above, middle and below, for along the direction of the gas, specifically included the above distance $30 \mathrm{~mm}$ from the top of the specimens, the block at the center of the products, and the block a distance $30 \mathrm{~mm}$ from the bottom. The size of the specimen was $(100 \times$ $100 \times 100) \mathrm{mm}$ and a group of specimens was three pieces.

The chosen specimen was dried with an electric drum dryer to remain constant quality, then cooling to a temperature of $20 \pm 5{ }^{\circ} \mathrm{C}$ and maintained for $20 \mathrm{~min}$. Next it was soaked in a water tank at a temperature of $20 \pm 5{ }^{\circ} \mathrm{C}$, and the level of water exceeded the height of specimen by $30 \mathrm{~mm}$, held for $5 \mathrm{~min}$, then removed, and kept for $30 \mathrm{~min}$ at a temperature of $20 \pm 5^{\circ} \mathrm{C}$. Finally, in the selected electric drum dryer, it was dried for $7 \mathrm{~h}$ at a temperature of $60 \pm 5{ }^{\circ} \mathrm{C}$, then cooled for $20 \mathrm{~min}$, later soaked in the water at a temperature of $20 \pm 5^{\circ} \mathrm{C}$, for one cycle. The selected times of the dry-wet circulation were $(0,30,60,150,270$ and 340) $\mathrm{min}$.

\subsection{Mechanical test methodologies}

The moisture in the specimen was maintained at $8 \%$ to $12 \%$. The specific methods were as follows: chose the brush, evenly apply water on the specimen, then select the PP bag packaging specimen for $1 \mathrm{~d}$ at $20^{\circ} \mathrm{C}$, use the water to achieved a uniform distribution, chose the universal mechanical testing machine for testing the compressive strength and the splitting tensile strength. And the size of specimen was $(100 \times 100 \times 100) \mathrm{mm}^{3}$.

\subsection{Pore structure test methodologies}

Scanning electron microscopy was chosen to observe the micropore structure of the autoclaved aerated concrete, the size of test block was $(10 \times 10 \times 10) \mathrm{mm}^{3}$. Image-Pro-Plus software was selected for a binary image of the pore structure, so as to provide a calculated and quantitative characterization of the pore diameter distribution.

\section{RESULTS AND DISCUSSION}

\subsection{Mechanical properties of autoclaved aerated con- crete under dry-wet circulation}

Figure 1 shows the compressive strength and splitting tensile strength of the autoclaved aerated concrete under dry-wet circulation. When the dry-wet circulation increased, the tendency of the compressive strength and splitting tensile strength of autoclaved aerated concrete was to decrease after first increasing. With dry-wet circulation times of $30 \mathrm{~min}$, the compressive strength was greater than the specimen with no dry-wet circulation. The compressive strength was $4.27 \mathrm{MPa}$, increased by $0.47 \%$ compared to the no dry-wet circulation. As we continued to increase the times of dry-wet cycle, compressive strength showed a tendency to decline, such as with times of the dry-wet cycle equal to $(60,150,270$ and 340) min, its compressive strength was (4.24, 4.23, 4.16 and 3.99) $\mathrm{MPa}$. When the dry-wet circulation times reached $340 \mathrm{~min}$, the value of the compressive strength was the lowest, and had declined by $6.1 \%$ compared to the no dry-wet specimen.

The splitting tensile strength showed the same tendency as the compressive strength. When the dry-wet circulation times went up to $30 \mathrm{~min}$, the splitting tensile strength reached a maximum of $0.568 \mathrm{MPa}$, compared to the no dry-wet circulation, it increased by $0.53 \%$. And with the dry-wet circulation times increased to $(60,150$, 270 and 340$) \mathrm{min}$, the value declined, respectively, to $(0.563,0.562,0.556,0.541) \mathrm{MPa}$. Compared with the specimen that had no dry-wet cycles, the splitting tensile strength declined by $4.24 \%$, when the dry-wet circulation times went to $340 \mathrm{~min}$.

The reason for this behavior was that with an increase in the times of dry-wet circulation, the moisture was made to move in and out of the specimen more

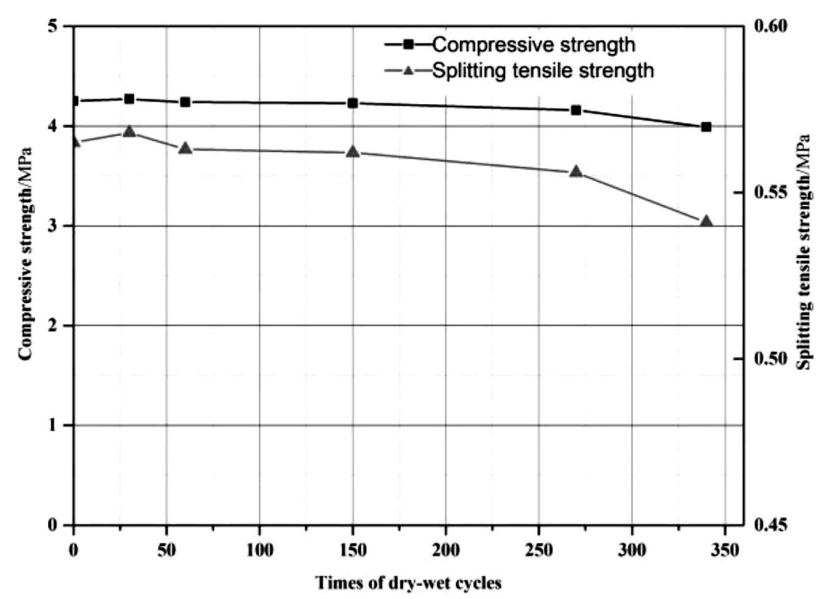

Figure 1: Effect of mechanical properties of autoclaved aerated concrete under dry-wet circulation 

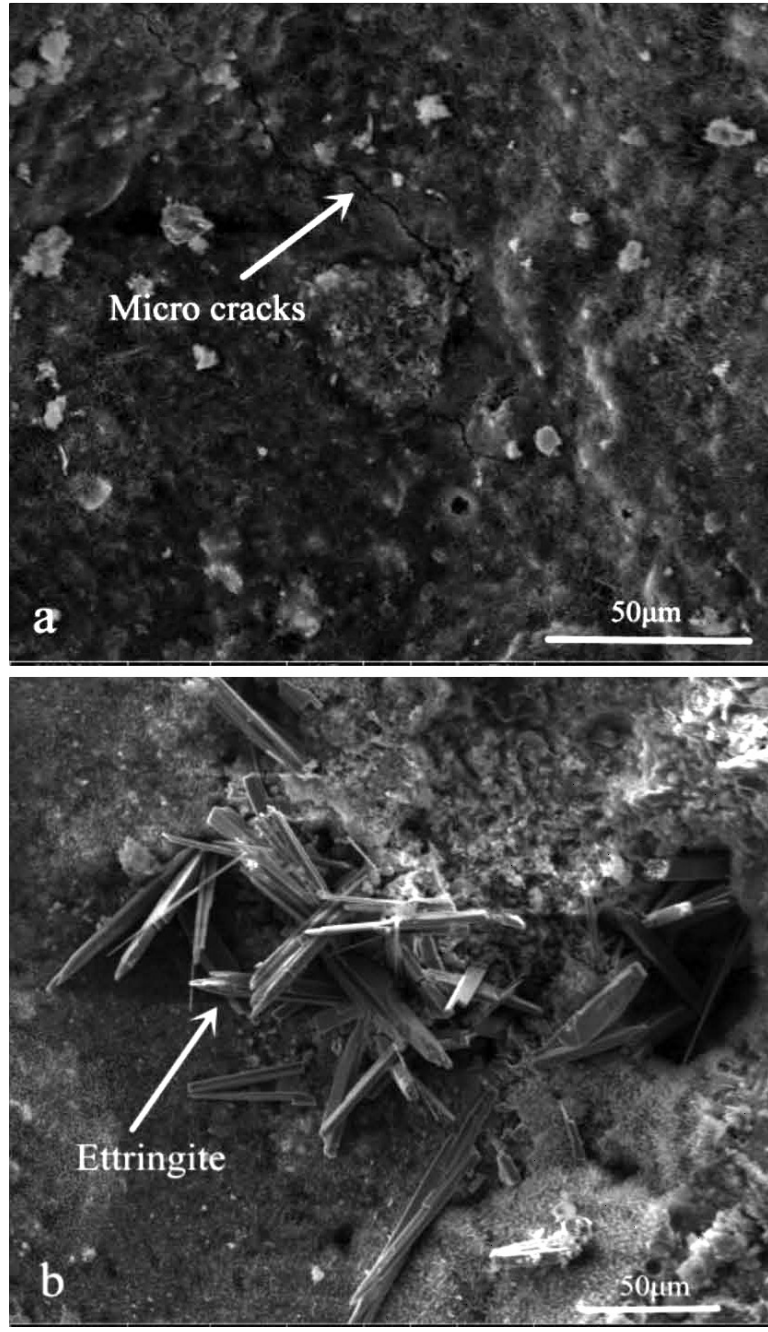

Figure 2: Scanning electron microscopy images of the autoclaved aerated concrete under dry-wet circulation: a) magnified 1600 times, b) magnified 1000 times frequently. For the times of dry-wet circulation equal to $30 \mathrm{~min}$, the influence of the hydration products on the sand particles was negligible, and hence the mechanical properties increased. As the dry-wet circulation times increased, the hydration products reacted further with the porous structure, thus resulting in a decrease in performance.

\subsection{Microstructure of autoclaved aerated concrete un- der dry-wet circulation}

Figure 2 shows SEM images of the autoclaved aerated concrete under dry-wet cycle times of $340 \mathrm{~min}$, and respectively magnified by 1000 and 1600 times. According to Figure 2a the internal cracks of the specimen appeared, with those microcracks expanded into large cracks due to the external conditions, which resulted in a degradation of the macroscopic performance, e.g., the strength and dynamic modulus of elasticity. Also, the generation of cracks erosion of other ions, caused further damage during the dry-wet circulation of the specimen. Figure $\mathbf{2 b}$ shows acicular ettringite, with the increased dry-wet circulation times, and the ettringite began to grow inside the crack, which results in the ettringite appearing in the pore structure.

\subsection{Pore structure of autoclaved aerated concrete un- der dry-wet circulations}

\subsubsection{Characterizing methods for the pore structure}

By employing the technology of image analysis we analyzed the pore structure. Figure 3 shows the methods. First, smear the surface of autoclaved aerated concrete to the color of black, next binarization of the image through the soft of the Image-Pro-Plus, for the pore structure more clearly, then identify the pore structure with the

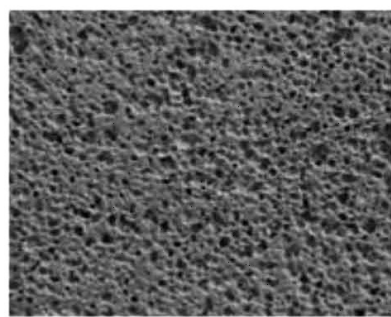

\section{Smear to black}

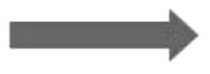

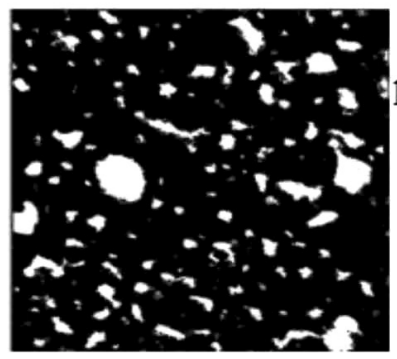
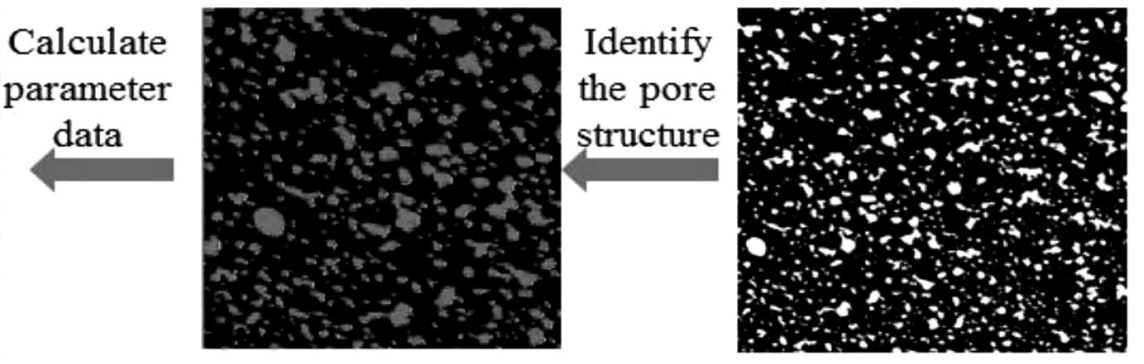

Figure 3: Schematic diagram of autoclaved aerated concrete pore structure analysis 
X. HE et al.: EFFECT OF DRY-WET CIRCULATION ON THE MECHANICAL PROPERTIES AND PORE STRUCTURE ...

Image-Pro-Plus and count it. Finally, obtain the parameter of the pore structure for the pore size.

\subsubsection{Pore size distribution}

Figure 4 shows the distribution of the pore size. When the time of the dry-wet circulation was 0 , the distribution of the pore size concentrate was $0.1-0.5 \mathrm{~mm}$, and the ratio reached $48.25 \%$. With an increase of the dry-wet circulation times to $30 \mathrm{~min}$, the pore size distribution was concentrate to $0.5-1.0 \mathrm{~mm}$, the propor- tion was $46.09 \%$, and with dry-wet cycles times increased to $(60,150,270$ and 340) $\mathrm{min}$, the aperture size concentrate was $1.0-1.5 \mathrm{~mm}$, the percentage achieved was $35.14 \%, 33.12 \%, 34.23 \%$ and $31.02 \%$, respectively. For the specimen that had no dry-wet circulation, the amount of pore size distribution that more than 1.5 $\mathrm{mm}$ is zero, and under dry-wet circulation, an aperture size distribution of $1.5 \mathrm{~mm}$ appeared, and the dry-wet circulation times reached to $(60,150,270$ and 340) min,
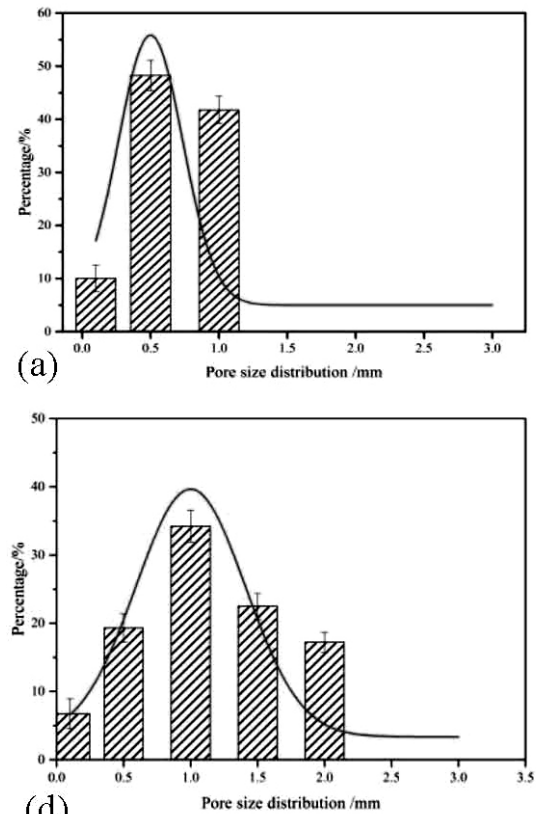

(d)
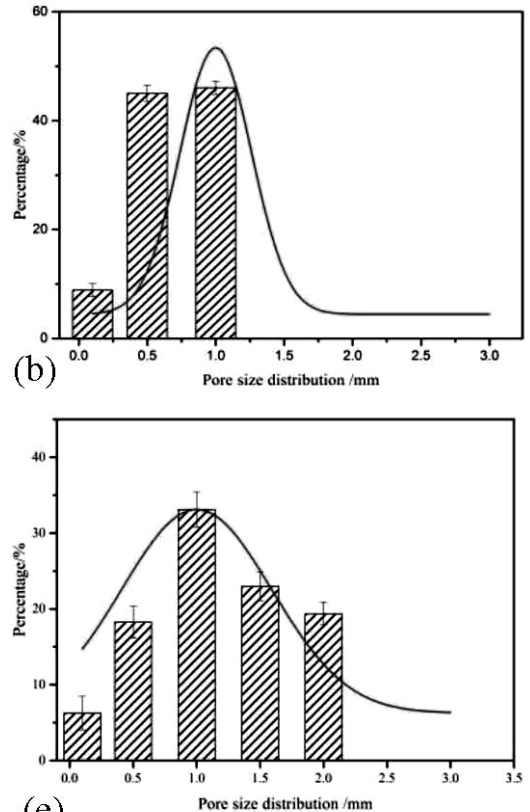

(e)
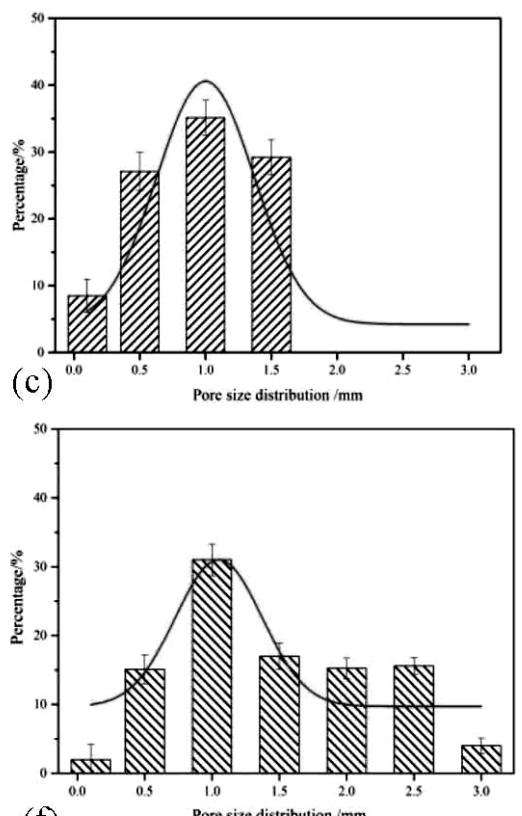

(f)

Figure 4: Pore size distribution of autoclaved aerated concrete under dry-wet circulation, a) to e) for dry-wet circulation times of $(0,30,60,150$, 270 and 340) $\mathrm{min}$

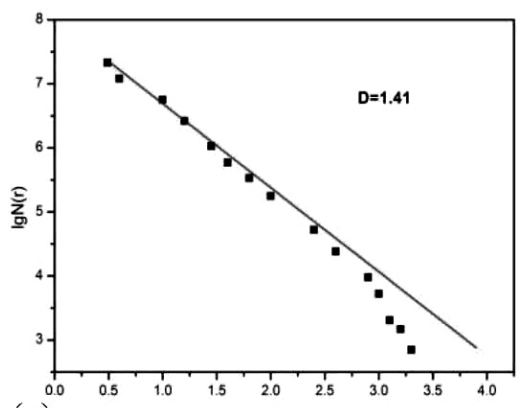

(a)

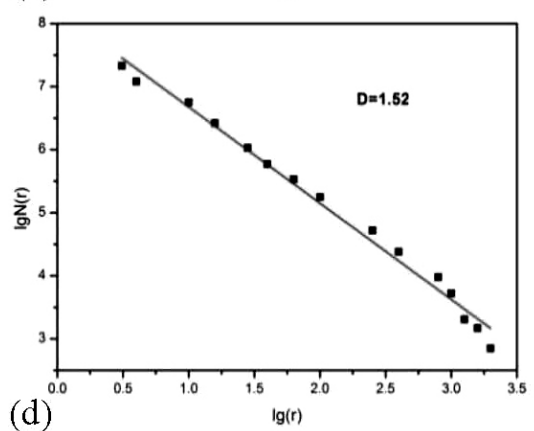

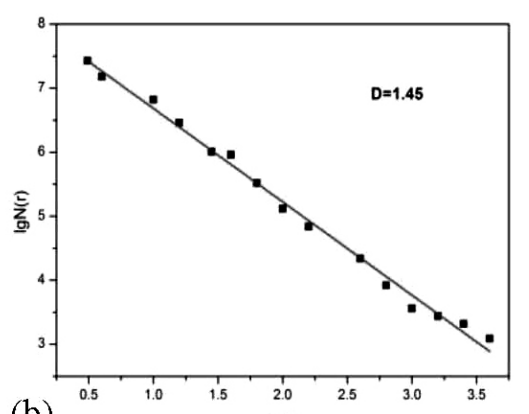

(b)

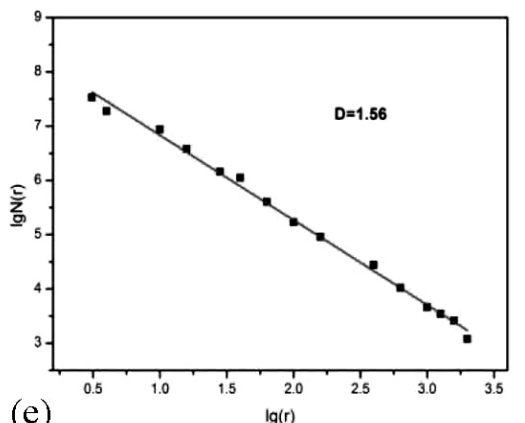

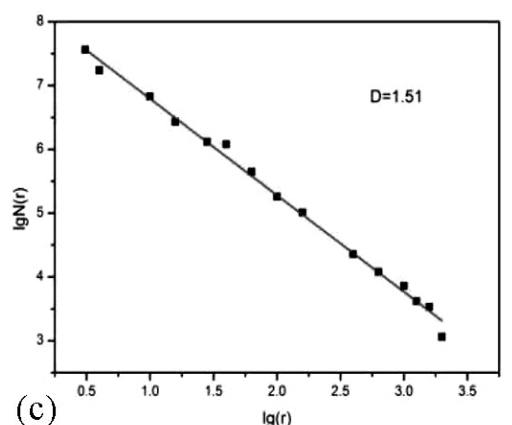

(c)

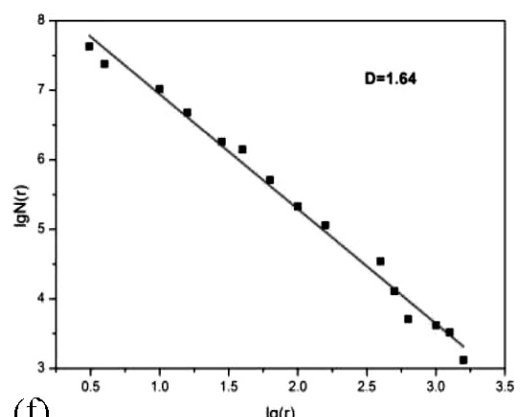

(f)

Figure 5: Fractal dimension of size pore distribution, a) to f) for dry-wet circulation of $(0,30,60,150,270$ and 340$) \min$ 
and the proportion, respectively, of $29.24 \%, 39.70 \%$, $42.38 \%$ and $39.70 \%$.

\subsubsection{Fractal dimension of the pore size distribution}

We used the method of box-counting dimension. The specific method was as follows: chose a square with side length of $r$ to cover the pore, and statistically the number of the square is $N(r)$, by changing the side length of the square, the statistical number corresponds to the square, obtained a series of corresponding points, the slope is the fractal dimension for $D_{\mathrm{c}}$. Equation (1) was used for the fractal dimension.

$$
D_{\mathrm{c}}=\frac{\mathrm{d}(\ln N(r))}{\mathrm{d}(\ln r)}
$$

The fractal dimension of the pore size distribution characterization for the uniformity of the pore size was shown in Figure 5, when dry-wet circulation times of $(0$, $30,60,150,270$ and 340) $\mathrm{min}$, the fractal dimension of the pore size distribution was $1.41,1.45,1.51,1.52,1.56$ and 1.64 .

Figure 6 shows the relations between the fractal dimension of the pore size distribution and the mechanical properties. The research showed the relations

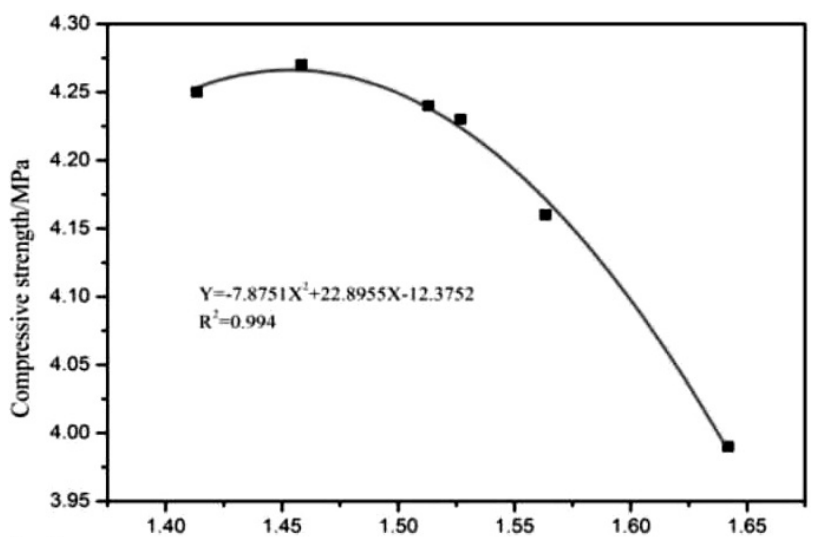

(a)

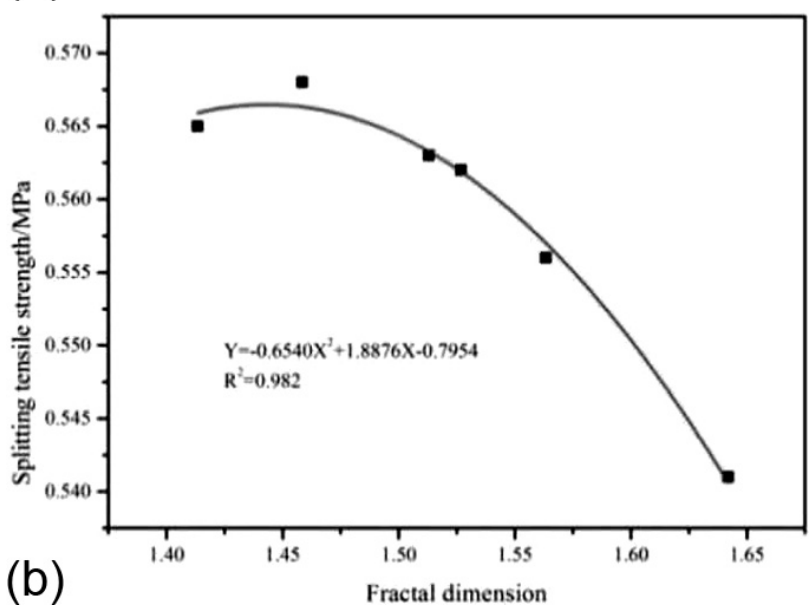

Figure 6: Relation between the fractal dimension and the mechanical properties: a) for the compressive strength, b) for the splitting tensile strength among the fractal dimension of the pore size distribution with the compressive strength and the splitting tensile strength. The results present a good quadratic correlation of the fractal dimension and the mechanical properties though the regression equation. The value of the fractal dimension increased, the compressive strength and splitting tensile strength tended to decrease. The result implies that the pore size distribution has an influence on the mechanical properties.

\section{CONCLUSIONS}

Dry-wet circulation is one of the most severe environmental conditions. The relationship between the mechanical properties and the pore structure of autoclaved aerated concrete under dry-wet circulation is discussed in this study. When the times of the dry-wet circulation increased, the compressive strength decreased after first increasing and the splitting tensile strength declined. For dry-wet circulation times of $340 \mathrm{~min}$, the compressive strength and the splitting tensile strength were $3.99 \mathrm{MPa}$ and $0.541 \mathrm{MPa}$, and reduced by $6.1 \%$ and $4.24 \%$, compared to the no dry-wet circulation.

The microstructure of the autoclaved aerated concrete under dry-wet circulation was obtained by SEM, and the results showed that ettringite emerged. Less ettringite may lead to better mechanical properties, but more can break the pore structure, and reduce the properties. For a quantitative characterization of the pore structure we used a binary image and Image-Pro-Plus for a clear pore structure. Then we calculated the pore diameter distribution, and compared the pore structure of the autoclaved aerated concrete under a dry-wet cycle. We chose the fractal dimension to characterize the pore size distribution and the value of the fractal dimension increase with the time of dry-wet circulation increase. The pore size distribution was found to affect the mechanical properties.

\section{Acknowledgments}

This research was supported by National Key R\&D Program of China (no. 2016YFC0700801-01).

\section{REFERENCES}

${ }^{1}$ K. G. Wakili, E. Hugi, E. Karvonen, L. Karvonen, P. Schnewlin, F. Winnefeld, Thermal behaviour of autoclaved aerated concrete exposed to fire, Cem. Concr. Compos., 62 (2015) 52-58, doi:10.1016/ j.cemconcomp.2015.04.018

${ }^{2}$ K. Kunchariyakun, S. Asavapisit, K. Sombatsompop, Properties of autoclaved aerated concrete incorporating rice husk ash as partial replacement for fine aggregate, Cem. Concr. Compos., 55 (2015) 11-16, doi:10.1016/j.cemcon-comp.2014.07.021

${ }^{3}$ C. L. Wang, W. Ni, S. Q. Zhang, S. Wang, G. S. Gai, W. K. Wang, Preparation and properties of autoclaved aerated concrete using coal gangue and iron ore tailings, Const. Build. Mater., 104 (2016) 109-115, doi:10.1016/j.conbuildmat.2015.12.041 


\section{HE et al.: EFFECT OF DRY-WET CIRCULATION ON THE MECHANICAL PROPERTIES AND PORE STRUCTURE ...}

${ }^{4}$ S. Rouchier, H. Janssen, C. Rode, M. Woloszyn, G. Foray, J. J. Roux, Characterization of fracture patterns and hygric properties for moisture flow modelling in cracked concrete, Const. Build. Mater., 34 (2012) 54-62, doi:10.1016/j.conbuildmat.2012.02.047.

${ }^{5}$ M. Campanale, M. Deganello, L. Moro, Effect of moisture movement on tested thermal conductivity of moist aerated autoclaved concrete, Transp. Porous media, 98 (2013) 125-146, doi:10.1007/ s11242-013-0136-z

${ }^{6}$ P. Reiterman, O. HoläApek, K. Polozhiy, P. Konvalinka, Fracture properties of cement pastes modified by fine ground ceramic powder, Advanc. Mater. Resea., 1054 (2014), 182-187, doi:10.4028/ www.scientific.net/AMR.1054.182

${ }^{7}$ H. Mefteh, O. Kebaïli, H. Oucief, L. Berredjem, A. Nourredine, Influence of moisture conditioning of recycled aggregates on the properties of fresh and hardened concrete, J. Clean. Product., 54 (2013), 282-288, doi:10.1016/j.jclepro.2013.05.009
${ }^{8}$ T. Kulovaná, E. Vejmelková, M. Keppert, P. Rovnaníková, Z. Keršner, R. Černý, Mechanical, durability and hygrothermal properties of concrete produced using Portland cement-ceramic powder blends, Struct. Cencr., 17 (2016), 105-115, doi:10.1002/suco.201500029

${ }^{9}$ H. Derluyn, D. Derome, J. Carmeliet, E. Stora, R. Barbarulo, Hysteretic moisture behavior of concrete: Modeling and analysis, Cem. Concr. Resea., 42 (2012), 1379-1388, doi:10.1016/j.cemconres. 2012.06.010

${ }^{10}$ T. Colinart, P. Glouannec, T. Pierre, P. Chauvelon, A. Magueresse, Experimental study on the hygrothermal behavior of a coated sprayed hemp concrete wall, Build., 3 (2013), 79-99, doi:10.3390/ buildings3010079 